\title{
Bank stems the loss of employees returning from abroad
}

Talent-management system helps to keep people loyal

By Liza Howe-Walsh, senior lecturer in human resources at Portsmouth Business School, University of Portsmouth, UK

\begin{abstract}
Purpose - This paper aims to develop a greater understanding for the problems faced by returning employees after an expatriate assignment.

Design/methodology/approach - Qualitative semi-structured interviews were undertaken to create a multi layered perspective of repatriation within the organization.
\end{abstract}

Findings - The inconsistent application of the global mobility policy contributed to the dissatisfaction of all stakeholders involved with the repatriation of staff. There was fundamental lack of talent management due to the lack of clear lines of responsibility associated with repatriating an employee.

Practical implications - The findings highlight the need to audit global mobility policy and practice to ensure policies are interpreted and applied consistently. The issue of multiple stakeholders identifies the need to ensure clear lines of responsibility are required when managing repatriates.

Social implications - The paper identifies fair and consistent treatment of employees enhances the banks reputation to manage their talent effectively.

Originality/value - This paper draws upon the views of multiple stakeholders including: Line managers; human resources practitioners as well as repatriates.

Article type: Case study

Keyword(s): Talent management; Retention; Multinationals; Banks; Repatriation. $\mathrm{H}$

One of the top five UK based international banks wanted to understand why so many of its repatriated staff left the organization after a developmental assignment. The aim was to stem the flow of talent and improve the bank's global-mobility policy and how this is delivered. The bank adopted one global-mobility policy that applies across the UK, Americas and Asia Pacific to be implemented across the regions. The implication is that all regions will interpret and implement the policy consistently.

Why repatriation issues are important 
For many organizations the statistics of retaining employees after a long-term expatriate assignment are poor. Various sources from industry and academia indicate that up to 50 percent of repatriates leave the organization within 12 months of their return. The cost relates not only to the amount of the assignment, four to five times their salary, but importantly the loss of retaining the knowledge of skilled staff.

\section{What the bank did}

The perceptions of the stakeholders involved with repatriation were sought through an independent researcher. Information about repatriation was gathered during multiple in-depth semi-structured interviews conducted with; repatriates; humanresource business partners home and host; the international human-resource manager as well as home and host line managers. Generating qualitative data enabled far deeper insights into the way employees of the organization experienced repatriation and provided the opportunity to verify the repatriation process. In addition the global mobility policy was reviewed.

\section{What the bank found}

\section{Global mobility policy}

The key elements of most mobility policies for long-term assignments are contained in one international relocation policy. In general the view is to reverse what happened on the way out. This includes potential repatriation allowances, shipping costs, temporary accommodation, tax assistance and so on. The organization policy was analyzed and provided clear intent to transfer valuable knowledge back to the home organization as well as encourage other employees to undertake future assignments and retain talent.

The policy does not state clearly who is responsible for the tasks that are necessary in order to repatriate. While the onus is upon the repatriate to piece together what is required there is an obvious tension with the expectations of what assistance is provided by human-resource business partners. This links to one of the overall issues highlighted by repatriates and line managers alike in that they perceive HR to be a seamless function when in fact the HR function is made up of multiple HR departments.

When reviewing your own organizational policy it is important to consider whether your policy is able to realistically set the expectations of the repatriate and line managers. Do you have a policy and practices that actually deliver what you want? It is essential to audit the policy content and ensure that all stakeholders consistently apply the policy.

\section{Repatriation process - lessons learned}

Across all the stakeholders there was a clear understanding that timing of events for the repatriation was crucial. The organization produces a monthly report to indicate return dates using a commonly found traffic-light system, six months before return labelled green, three months before return amber and one month before return red. Unfortunately despite the intention that the human-resource business partners home and host would liaise with the line managers to discuss the return position there was often a fragmented approach to how this was achieved. The end dates and information required to decide on a return position was discussed with the line 
managers inconsistently. Host line managers reported that they were left to find new positions for the repatriate and wanted more help from HR. In part the additional support required by HR could be related to the lack of understanding from humanresource business partners regarding the intended repatriation process.

Training of all stakeholders of the policy and process is required in order to ensure the correct interpretation and resulting action are taken. Further information regarding responsibilities of each stakeholder should be documented and easily accessible.

Within the process it is essential to adopt a rigorous approach to retention of repatriates. How does the company maintain information regarding leavers? Who and how gains data regarding leavers? For example during an exit interview (if conducted) does the question arise as to whether the employee has been on an expatriate assignment within the last 24 months? Who undertakes the interview, does he or she report the results and to whom?

Talent pools are widely reported to be part of the organization's approach to ensuring that future leaders and crucial employees are recognized and developed to nurture their contribution to the organization. Expatriates should be maintained in the talent pool to ensure that host and home human-resource business partners share appraisal and performance-management information with line mangers to improve the opportunity to identify a return position.

Third-party providers are also stakeholders in the process of repatriation. Many vendors conduct their own internal feedback to gauge satisfaction of their services; however the results are not always shared in any depth with the organization. Therefore a review of the timing and actions taken during the planned return of an assignee is essential with all stakeholders. This requires responsibility for actions to be clearly determined and understood between all of the stakeholders to improve the overall process.

\section{Multiple stakeholders}

It is essential to review which stakeholders are involved in the process. It is likely that, unless the stakeholders are aware of each other and have clear lines of responsibility, there will be inconsistent application of the global-mobility policy and practices. Unfortunately the more stakeholders involved within the process the more likely the repatriate will be passed from pillar to post, affecting their perception of support the organization provides. The result is a poor experience for the repatriate and frustration for all those concerned with retaining talent.

There remains a void in understanding the importance of $\mathrm{HR}$ activities in order to improve the repatriation experience. The fundamental issue is not to assume that HR works seamlessly together if you have separate HR functions, then each function has to ensure who is responsible for each part of the repatriation process.

Finally by reviewing the repatriation process the organization can enhance the experience of the repatriate as well as the other stakeholders. Any policy improvements are part of an iterative process. Reviewing policy and practice is an annual activity to ensure the HR policy delivers what was intended to improve the experience of stakeholders and ultimately improve the retention rates of repatriates. 
The bank has since revised its global-mobility policy and made online training available to stakeholders involved in repatriation. It reports a positive impact.

More importantly the benefit to employees is that the improved process demonstrates the organization's commitment to global mobility and effective talent management.

\section{Note}

Liza Howe-Walsh is senior lecturer in human resources at Portsmouth Business School, University of Portsmouth, Richmond Building, Portland Street, Portsmouth PO1 3DE, United Kingdom. Tel: +44 (0)23 9284 4051; fax: +44 (0)23 92844037 ; email: liza.howe-walsh@port.ac.uk

\section{Box-out quotes}

Up to 50 percent of repatriates leave the organization within 12 months of their return. The cost relates not only to the amount of the assignment, four to five times their salary, but importantly the loss of retaining the knowledge of skilled staff.

It is likely that, unless the stakeholders are aware of each other and have clear lines of responsibility, there will be inconsistent application of the global-mobility policy and practices.

Word count: $1272 / 1435$

File name: HV23N2HOW 